\title{
Trazos xerais da tradición gramatical galega
}

Xosé Manuel Sánchez Rei

Universidade da Coruña

sanrei@udc.es

\begin{abstract}
Resumo:
A tradición gramatical galega comeza no século XIX, en contraste co que aconteceu coas linguas do seu contorno, que principian o seu percurso filolóxico na Idade Moderna. Tal demora é produto da colonización española e esta, dunha maneira ou doutra, está así mesmo presente nas primeiras gramáticas do galego: a carga diglósica que transparece nunha boa parte delas, a constante comparación entre galego e castelán, a súa falta de socialización porque a lingua se achaba excluída de certos ámbitos etc. son algúns dos trazos que singularizan a tradición gramatical galega e que serán abordados nestas páxinas
\end{abstract}

Palabras chave:

gramática, gramáticas galegas, características das gramáticas galegas.

\begin{abstract}
:
The Galician grammatical tradition has its origins in the $19^{\text {th }}$ century, in contrast with other neighbouring languages in which philological studies started to appear in the Modern Era. Such a delay is the result of the Spanish colonization, whose influence is present somehow in the first Galician grammars. The large percentage of diglossia in some grammars, the constant comparison between Galician and Castilian, the lack of socialization due to the exclusion of Galician from some areas, and so on are some of the features characterising the Galician grammatical tradition that will be approached in this paper.
\end{abstract}

Key words:

grammar, Galician grammars, characteristics of the Galician grammars.

\section{Introdución: o concepto de gramática e a lingua galega}

O termo gramática remóntase, a través do latín, a unha palabra grega cuxa tradución viría corresponder a 'a arte de escribir', segundo apunta Lyons (1986: 137). Mais xa desde os principios históricos da erudición helénica, o vocábulo adquiriu un sentido moito máis amplo e estendeuse ao estudo completo da linguaxe, tal e como se transmitiu desde os gregos aos seus sucesores. Son de salientar os fins para que era concibida a gramática neses primeiros momentos, xa que se entendía como a arte de explicar os escritos arcaicos, ou sexa, Homero na Grecia alexandrina ou o sánscrito nos textos sagrados da India; neste sentido, facendo case equivaler o oficio de gramático ao de filólogo, é como cobran sentido as seguintes palabras de Dionisio de Tracia (circa 190-70 a.d.n.e): 
A gramática é o coñecemento do dito sobre todo por poetas e prosistas. As súas partes son seis: primeira, lectura coidada segundo a prosodia; segunda, explicación das figuras poéticas que houber; terceira, interpretación en termos usuais das palabras raras e dos argumentos; cuarta, procura da etimoloxía; quinta, exposición da analoxía; sexta, crítica dos poemas, que é a parte máis bela de todas as da gramática ${ }^{1}$.

A historia da teoría lingüística occidental, como continúa a nos indicar Lyons, foi, en primeiro lugar, a historia do que os estudiosos de distintas épocas quixeron introducir dentro do ámbito da gramática, tomada en sentido máis amplo. Durante todo o mundo romano e o medieval a única gramática que se ensinaba era a do latín, un latín máis ou menos identificado coa lingua literaria dos clásicos que presentaba unhas regras tiradas deses auctores antigos. Só será coa Idade Moderna cando os idiomas romances, os vulgares, por unha serie de acontecementos políticos, culturais etc. comecen a contar coas súas propias gramáticas, que, herdeiras desa tradición occidental, continuaban a identificar a maior calidade lingüística cos textos dos máis salientábeis escritores. Durante o século XVIII, porén, principian a se formular novas preguntas, como é a transcendente cuestión da orixe da linguaxe, e conclúese na existencia dunha gramática xeral, segundo a cal os distintos idiomas posúen un fundamento común; se diferiren, será antes debido á maior ou menor aptitude dos pobos para poderen razoar rigorosoamente e con certa calidade (Guiraud 1964: 11), mais non á estrutura propia de cada lingua. Na centuria seguinte sáese desta concepción metafísica e o estudo do feito lingüístico é analizado segundo bases científicas; neses cen anos é de vital importancia a figura de Ferdinand de Saussure, de formación neogramática, que se tornará a fonte de que partirá todo o estruturalismo posterior.

Ao longo dos máis de vinte séculos de tradición clásica tivo, en consecuencia, notábel relevancia o que se entendeu baixo o concepto de gramática, e non de estrañar que tamén na actualidade continúe a ter vital importancia o significado que se agocha detrás desa palabra, existindo mesmo varias posibilidades de definición ${ }^{2}$. Mais a Galiza, por causas coñecidas, ficou á marxe de calquera especulación científica sobre a súa propia lingua, de costas a respecto do que se entendia por gramática na

Para a tradución do texto deste autor clásico baseámonos na edición preparada por Bécares Botas (2002)

2 Repárese, por exemplo, nas que aparecen no dicionario de Lewandowski (1992, s.v. gramática): a) manual ou libro de regras que describe a construción dunha lingua ou estabelece normativamente como válidas certas regras de uso; b) campo dentro da lingüística que investiga a constitución e variación das palabras, grupos de palabras, frases, mais que non toma en consideración a fonética e a fonoloxía, como tampouco a semántica e a formación de palabras; c) construción lingüística, estrutura inmanente da linguaxe, o sistema de regras en funcionamento que subxace á linguaxe; e d) conxunto de regras, das posibilidades dunha lingua, representadas nunha teoría da gramática como modelo e teoría parcial dunha teoría da linguaxe, ou como teoría lingüística universal. 
Idade Moderna, de costas á procura da gramática universal, á marxe da especulación arredor da orixe da linguaxe e fóra tamén dunha reflexión promovida polo mundo académico. Notemos que a primeira definición do concepto de gramática entre nós corresponde a Valladares (1970: 11), quen, deixando transparecer a influencia clásica, se refire a ela desta maneira en 1892:

Gramática gallega es el arte de hablar y escribir correctamente en gallego por medio de letras, cuyas diferentes combinaciones forman las sílabas de que se componen las palabras.

E, como se torna obvio deducir, non é por un acaso que a primeira vez que se define gramática para o galego sexa nos anos finais do século XIX, e tampouco é por unha casualidade que estea en español, o que revela unha hipertrofia nas relacións entre destinatario e autor. Así pois, o feito de que estea redixida nese idioma e a circunstancia de que apareza no solpor decimonónico conforman dous dos trazos das particularidades da nosa tradición gramaticl; ao longo do presente traballo imos expor e desenvolver as, ao noso ver, características fundamentais das nosas gramáticas no seu percurso histórico iniciado no Rexurdimento. Os traballos aparecidos nos anos finais do século XX e nos principios da centuria seguinte, distintos canto a calidade, destinatario, rigorosidade etc., serán tratados noutro lugar máis pormenorizadamente.

Antes de máis, convén salientarmos que se confrontarmos cada obra en particular con aquelas que fan parte do noso legado gramatical, imos achar trazos non sempre coincidentes coas restantes publicacións, polo que se evidencia que cada gramática posúe unhas características de seu. Mais é así mesmo certo que, se perspectivadas no seu conxunto, proporcionan unha serie de puntos en común, especialmente as anteriores ás publicadas desde a década de 80 do pasado século. E coidamos que tales singularidades compartilladas son susceptíbeis de se agruparen nos apartados en que desenvolveremos esta aproximación.

\section{Aparición e desenvolvemento tardío}

O primeiro trazo da nosa tradición gramatical é a súa demora. Durante a Idade Moderna ten lugar o rexurdir das linguas vulgares e a súa apoloxización a respecto do latín, como sinala Kossarik (2002: 182) para os séculos XVI-XVII en Portugal, período caracterizado, nas súas propias palabras, pola "defesa e ilustração, ou apologia, dos vernáculos". Aínda que xa Dante na súa obra De Vulgari Eloquentia (1303-1304) manifestou o seu interese polas linguas románicas, até nun sentido comparativista, e ponderou, así mesmo, a súa dignidade literaria, é a época coñecida como Renacemento cando van saír do prelo as primeiras gramáticas para 
as linguas dos estados modernos, produtos tamén dese novo contexto histórico, cultural e político. Deste modo, o francés inaugura o seu percurso gramatical coa obra Le tretté de la grammere françoeze, de Louis Meigret, que se edita en 1550; o italiano, por súa vez, ve aparecer Le regole della lingua fiorentina, de Lorenzo de Medici, obra publicada en 1495; o caso que máis próximo fica do galego, o portugués, abre a reflexión filolóxica coa Grammatica da lingoagem portuguesa, de Fernão de Oliveira, dada a lume en 1536; e mesmo o español inicia nestes anos a súa particular singradura gramatical coa Gramática de la lengua castellana, de Antonio de Nebrija, saída do prelo en 1492.

Polo contrario, o noso país, sometido a intereses alleos, non coñece ese rexurdir e esa apoloxía da súa "lingua vulgar" e fica valado petreamente pola influencia de Castela a calquera cultura europea. O seu idioma propio, o galego, é entendido propositadamente cal unha sorte de dialecto do español, como un modo rústico e iletrado de se expresaren as persoas incultas e as máis desfavorecidas socialmente $^{3}$ e non terá a súa primeira gramática, se é que pode recibir tal nome, até ao ano 1864, en que Francisco Mirás publica en Santiago de Compostela o seu Compendio de Gramática gallega-castellana. Aínda que desde o século XVIII algúns ilustrados galegos, e en especial o Padre Sarmiento, viñan demandando a realización de obras destinadas a estudar a lingua do país, son ilustrativas neste sentido as coñecidas palabras de Rosalía de Castro no seu prólogo de Cantares Gallegos cando, un ano antes da publicación da obra de Mirás, describía o abandono e a deixadez en que se encontraba o estudo do noso idioma na época final do século XIX:

Foy este ó movil principal que m'impeleu a pubricar este libro que, mais que nadie, conoço que necesita á indulxencia de todos. Sin gramática nin regras de ningunha clás, ó lector topará moitas veces faltas d'ortografia, xiros que diosoarán ôs oidos d'un purista; pró ô menos, e prá disculpar en algo estes defectos, puxen o mayor coidado en reprodusir ó verdadeiro esprito d'ó noso pobo, e penso qu'o conseguin en algo... ( $C G 11)$.

\footnotetext{
3 A se basearen na variedade literaria ou padrón da corte portuguesa, tamén para os gramáticos lusitanos o galego será entendido como unha fala do pobo, como apunta Vázquez Corredoira (1998: 65): o noso idioma, "que na época em que se empreendia a gramaticalização do português ficara reduzido à oralidade e que perante os gramáticos lusitanos aparece como um desvio arcaico, rústico e dialectal da norma literaria portuguesa serve, quando mencionado (sempre incidentalmente) para notar reprobatoriamente certos fenómenos linguísticos comuns ao continuum galaico-interamnense excluídos do padrão português".

4 Di ao respecto Fernández Salgado (2000: 121): "En comparanza con outras tradicións lingüísticas, a tradición gramatical galega é un desenvolvemento moi recente. Aparentemente non houbo tratados gramaticais medievais coma os compostos en provenzal a pesar da florecente lingua literaria; e non houbo gramáticas renacentistas coma as do castelán e portugués”.
} 
O desfase cronolóxico entre os finais do XV ou os comezos do XVI co ano en que se publica o Compendio é de cando menos tres séculos e durante estas centurias o resto das linguas do noso contorno non foi só acrecentando o número de obras de gramática, senón que tamén manuais e traballos posteriores foron facendo posíbel que se coñecesen mellor os idiomas obxecto de análise lingüística. O portugués, por exemplo, conta cunha vigorosa tradición gramatical desde a publicación en 1536 da Grammatica da lingoagem portuguesa de Fernão de Oliveira até aos últimos contributos de que temos notica, como por exemplo a Gramática da Língua Portuguesa publicada recentemente pola editora lisboeta Caminho (GRA 2003). Desde unha perspectiva galega é absolutamente sorprendente a cantidade de títulos que recolle Cardoso (1994) desde ese ano de 1536 até 1920. E eses traballos, que describían normalmente o portugués padrón lisboeta, en ocasións poden servirnos de axuda para sabermos algúns datos sobre determinados aspectos en relación ao estado do galego da época, sobre todo cando fan referencia a falares que non corresponden a esa variedade meridional e que son entendidos polos respectivos autores como "rústicos". Así, moitos dos fenómenos que reproban os gramáticos portugueses, como Barboza (1830), que son casuísticas típicas da oralidade lusitana, son tamén comúns ao noso idioma, como a epéntese, a metátese consonántica, a harmonización vocálica, a labialización etc., e, ao mesmo tempo, tamén se detectan na literatura contemporánea, sobre todo a do século XIX ${ }^{5}$ e a dos primeiros anos da centuria seguinte. Vexámolo cun exemplo: no capítulo dedicado aos "Vicios da Pronunciação" (Barboza 1830: 50-51), aparecen comentarios como os seguintes, en que se proscriben casuísticas igualmente detectábeis no galego:

Os Algarvios tambem dizem Pidaço, Cigueira, Pidir [...]. Porêm ninguem, como os Rusticos, faz tantas trocas de vozes humas por outras dizendo: Antre, Precurador, Proluxo, Rezão, Titôr em lugar de Entre, Procurador, Prolixo, Razão, e outros muitos.

Mas o peior vicio de todos, e o que se mostra mais rusticidade, he o de inverter os sons das palavras, perturbando a ordem de suas Syllabas, e dizer, por exemplo, Alvidrar por Arbitrar, Crélgo por Clérigo, Frôl por Flôr, Contrairo por Contrario, Maninconia por Melancolia [...], Percissão por Procissão, Preguntar por Perguntar, Prove por Pobre (Barboza 1830: 53-54).

Por outra parte, téndomos presente a demora que comentabamos máis arriba, non se pode obviar o feito de que as nosas gramáticas son publicadas nomeadamente non no Renacemento, mais en épocas de reemerxencia cultural, lingüística ou sociopolítica: non é casual que en pleno Rexurdimento decimonónico se escribisen catro traballos desta índole de moi desigual valía científica (Compendio de gramá-

\footnotetext{
5 Sobre a lingua literaria galega no século XIX, véxase Freixeiro Mato / Sánchez Rei / Sanmartín Rei
} (2005). Son tamén de utilidade Freixeiro Mato (2003), Sánchez Rei (2003) e Sanmartín Rei (2003). 
tica gallega-castellana, de Francisco Mirás, 1864; El habla gallega, de Cuveiro Piñol, 1868; Gramática gallega, de Saco Arce, 1868; Elementos de gramática gallega, de Valladares, 1892), e tampouco é debido a un acaso histórico que nos anos anteriores á Guerra Civil, coincidindo co Partido Galeguista, co Grupo Nós, coas Irmandades da Fala e co Seminario de Estudos Galegos, saísen do prelo significativamente outros títulos (Filología de la lengua gallega, de Santiago y Gómez, 1918; Compendio de gramática galega, de Ramón Alvariño, 1919; Gramática do idioma galego, de Lugrís Freire, 1922, cunha segunda edición en 1931; El idioma gallego. Historia, gramática, literatura, de Couceiro Freijomil, $1935)^{6}$. Transcorridos case trinta anos desde a contenda civil, cando a ditadura franquista abrandou un bocadiño as súas plúmbeas directrices ideolóxicas e censoriais, publícanse novas contribucións (Gramática elemental del gallego común, de Carballo Calero, editada inicialmente en 1966 e que alcanza a súa sétima edición en 1979; Gramática gallega, de Carré Alvarellos, 1967). Doutro lado, nos tempos en que, desaparecida xa a figura do ditador, o galego é materia de estudo no ensino público, tornan a se publicar dous representativos títulos (Gramática galega, de Álvarez / Regueira / Monteagudo, 1986; Nova gramática para a aprendizaxe da língua, de Costa / González / Morán / Rábade, 1988). Os últimos contributos dados ao prelo son, por un lado a obra en catro volumes de Freixeiro Mato Gramática da Lingua Galega (1998, vol. I: Fonética e Fonoloxía; 1999, vol. III: Semántica; 2000, vol. II: Morfosintaxe; 2003, vol. IV: Gramática do texto), e unha gramática máis resumida, do mesmo autor, que sae en 2002 (Manual de gramática galega), ano en que se tamén dá a lume a obra Gramática da Lingua Galega de Álvarez I Xove ${ }^{7}$.

A todas estas obras habería que acrecentar, así mesmo, a Grafía galega, de Fuco G. Gómez, publicada en 1927 na Habana e que, como indica Álvarez (2001: 3), foi concibida "como parte dunha Gramática teórico-praítico-etimológica da lingua galega, anunciada en catro volumes"; mais, como apareceron algúns problemas que impediron a súa publicación, o autor decidiu editar unicamente este traballo e deixar as restantes partes para cando as circunstancias así o posibilitasen. E tamén cumpriría facermos referencia á gramática de Aurelio Ribalta, Gramática gallega elementale, datada en 1940 e que, a día de hoxe, se acha inédita no Mosteiro de San Francisco de Santiago de Compostela (Fernández Salgado 2000).

6 Apropiámonos, pois, das impresións de Fernández Salgado (2000: 125), cando manifesta que como "as tres primeiras gramáticas publicadas que apareceron no cume do Rexurdimento decimonónico, as dúas primeiras gramáticas do período "Nós" apareceron nun momento de espertar nacionalista e de renovado auxe da actividade literaria na lingua vernácula".

7 Unha vez entregue o presente traballo para a súa publicación, saíron do prelo as obras de Hermida Gulías (2004) e Feixó Cid (2004), que, conforme dixemos máis arriba, serán motivo, xunto con outras novidades editoriais, dunhas consideracións específicas noutro lugar. 
O número de títulos é, como se poderá observar, cuantitativamente inferior ás circunstancias doutros países, mais non por iso debemos renunciar a el e caermos nunha crítica gratuíta para cos seus autores e autoras, nomeadamente no século XIX: eles foron os que, con distintos graos de éxito, con diferentes concepcións sobre o que merecía ser o galego culto, con desiguais medios ao seu dispor (por non os cualificarmos de "inexistentes" nos máis dos casos) e con diversas e desequilibradas (in)formacións filolóxicas, tentaron describir a nosa lingua en épocas certamente desfavorábeis, o que nos fai contemplármolos con sumo respecto aínda a non compartillarmos, ás veces, as súas opinións, as súas conclusións ou os seus modelos de análise en relación ao galego. Parafraseando as palabras da profesora García Negro cando estuda a figura de Lamas Carvajal (2001: 94), pódese convir en que eses investigadores son "solitarios solidarios": solitarios, porque non contaron co apoio institucional preciso, por non teren detrás de si unha masa social compacta que usase o galego e que puidese empregar os seus traballos; e solidarios, porque o seu amor polo país e pola lingua, a súa solidariedade co galego, en definitiva, foi o factor determinante que norteou as súas pesquisas.

Notemos, asemade, o difícil que tivo de resultar para eles abriren un camiño até entón inexistente e é posíbel que tamén lles deba ter sido moi complexo comezaren un labor que foi albo de críticas por parte dalgúns sectores, o que sen dúbida contribúe, se perspectivados desde hoxe, a notarmos e a valorizarmos o seu traballo aínda que poida ser cientificamente pouco rigoroso. Na nómina de detractores do movemento de rexeneración política, cultural, social e lingüística do país do século XIX, houbo algúns que negaron a posibilidade de se elaborar unha gramática, a incidiren propositadamente nunha certa diversidade dialectal do galego e subliñando ese variacionismo xeográfico como forte impedimento para esa finalidade. É o caso de Joaquín de Arévalo, autor dun artigo publicado en Galicia Revista Regional ( $\mathrm{n}^{\circ} .7,1888$ ), de que extraemos a seguinte citación; o fragmento que reproducimos ilustra ás claras cal é a opinión do autor de Ocios de camarote sobre este particular:

De aquí toman pie algunos publicistas para exigir una gramática oficial, única y suprema, que reglamente este caso y ponga en orden en esta barahunda; un código que nos traiga la unidad y verifique la reversión al gallego enxebre primitivo; es decir un puntal para este edificio que se desmorona. Quieren que se legisle lo ilegislable; que se reglamente el vicio; planchar lo desgarrado para darle visualidad. Pensando, con razón, que los regionalistas de las otras provincias deseen lo mismo, vamos á llenar el mundo de gramáticas, cuando una para cada nación es lo suficiente, después de bien escrita y de bien sabida. Escuelas, es lo que hace falta que no gramáticas sensibles de una lengua que solo es un adorno [...].

¡Ah!... respeto que se conserve el gallego como un monumento de cariño; como se conserva el latín, por conveniencia, y el griego, que nadie habla, 
como un manantial etimológico; pero no le alcemos gramáticas; dejémosle que viva descuidado y abandonado á si mismo, que así será más bello. No le sujetemos al compás del arte y de las pretensiones, no le pongamos ligaduras pedagógicas, y dejémosle que brote espontáneo y puro, tosco y selvático, lleno de ignorancia, de buena fe y de mimo (en Hermida 1992a: 347-348).

Finalmente, deixando de parte as gramáticas sincrónicas e as ideas de Joaquín de Arévalo, temos de mencionar dous contributos de carácter diacrónico ${ }^{8}$, como son, por un lado, os Elementos de gramática histórica gallega, de Vicente García de Diego, que saen en 1909 (García de Diego 1984), e, por outro, a primeira Gramática histórica galega, en dous volumes, un dedicado á fonética e á morfosintaxe e outro á lexicoloxía, do profesor Manuel Ferreiro, publicados nos finais do século XX (Ferreiro 1995, cunha cuarta edición en 1999; e 1997, editado por segunda vez en 1999). A pesar de que ambos os traballos están dedicados ao estudo histórico do galego, decidimos incluílos nesta relación pola importancia que representan, sobre todo a obra deste último autor, que veu cubrir un baleiro existente desde había moitos anos. É preciso, así mesmo, facermos mención ao traballo de Couceiro Freijomil El idioma gallego (1935), miscelánea de literatura, historia e gramática que pretende condensar todos os coñecementos arredor do galego e da súa produción literaria existentes na altura.

\section{Escasa ou nula incidencia social}

É este outro trazo caracterizador dos máis dos títulos da nosa tradición filolóxica e que, a carón doutros factores, leva retrasado, ao noso ver, non podermos contar cunha variedade unificada até aos finais do século XX. Así as cousas, ora por o galego non ser lingua oficial, coas consecuencias sociais que isto implica (ausencia na admistración, no ensino, nos documentos oficiais etc.), ora por ser apenumbrado a lingua oral e familiar, non se fixo necesario contar cunha descrición da súa fenomenoloxía gramatical practicamente até ás décadas finais do século XX, precisamente porque se non sentía a necesidade de coñecer e estudar unha lingua relegada á oralidade e á coloquialidade ágrafas. As palabras que seguen, tiradas do prólogo de Rosalía de Castro a Follas Novas e aplicábeis nun principio ao destinata-

8 Contando cos apuntamentos de Rodríguez (1900) para a edición da Crónica Troyana de Andrés Martínez Salazar, habería talvez que acrecentar a nómina de traballos diacrónicos, mais non nos pareceu conveniente facelo por dous motivos principais: a) trátase do estudo lingüístico desa obra en particular e non de todo o galego-portugués medieval, co que os seus horizontes son conscientemente máis limitados que os dunha Gramática ao estilo convencional, sexa de carácter diacrónico ou sincrónico; b) a inclusión dese traballo, importante no seu momento, levaríanos a considerarmos tamén todas as introducións e os estudos lingüísticos que figuran noutras edicións de textos medievais e mesmo modernos, e non se poden ter en conta xustamente por non seren gramáticas. 
rio natural da súa produción artística, o pobo galego, serven igualmente para o público receptor dos diferentes estudos sobre a nosa lingua:

Creerán algús, que, porque, como digo, tentey falar d'as cousas que se poden chamar homildes, é por que m'esprico n'a nosa lengoa. N'é por eso. As multitudes d'os nosos campos tardarán en lêr estos versos, escritos á causa d'eles, pero sô en certo modo pra eles (FN XXVII-XXVIII).

E esas multitudes do noso mundo tradicional en que se conservou a lingua demoraron, con efecto, moito tempo en teren acceso ás gramáticas e dicionarios galegos. A pesar de existiren obras de recoñecida valía científica no seu tempo, como a de Saco Arce, a maioría dos títulos non contou coa implantación social que precisan os traballos desta índole. Isto evidénciase, máis unha vez, facéndomos un seguimento dos textos dos nosos escritores clásicos, que, na súa maioría, non tiveron en conta as indicacións que os diferentes autores lles ían proporcionando a través dos seus traballos e, en consecuencia, continuaron a escribir como xulgaban máis oportuno ou máis acorde co que eles entendían como 'lingua galega'. A presenza nunha boa parte dos escritores e das escritoras dos séculos XIX e XX de vocábulos tirados directamente da lingua medieval, do portugués, de pseudogaleguismos e mesmo de casuísticas de marcada proveniencia popular así o parece corroborar. Non teñen perda, pois, as seguintes palabras, de Aurelio Ribalta, cando se refire a esa escasa ou nula socialización en 1916 nas páxinas de Estudios Gallegos:

En gallego ai poucas gramáticas; pro e que a xente non pide ter mais. Nas botan de menos. As moitas gramáticas das outras linguas responden aas nezecesidás da enseñanza. Pro en Galizia non se estudia o gallego, depréndese sin libros [...]. Por esta razón "de feito", non "de razón", abonda ben con satisfazere as nezesidás dos eruditos, dos curiosos, dos literatos (tirado de Fernández Salgado 2000: 124).

Obviamente, e como apunta Ribalta, en cenáculos ilustrados as nosas gramáticas eran coñecidas. Sabemos, por exemplo, que a obra de Saco Arce foi, durante moito tempo, a fonte por que foi coñecido o galego en ámbitos e circuítos especializados do país e para moitas persoas interesadas foi a referencia máis preclara das poucas que había sobre a nosa realidade linguiística. Un bo expoñente desa predicación en tales circuítos témolo no compilador do Cancionero popular gallego, José Pérez Ballesteros, antigo mestre e amigo persoal de Saco Arce, quen segue fielmente as indicacións que aparecen na Gramática; o colector, que coñecía bastante ben a realidade da lingua dada a súa dedicación e preocupación pola literatura tradicional, apunta a rodapé comentarios, explicacións, particularidades gramaticais etc., moitas delas inspiradas directamente no texto de Saco Arce. Por exemplo, é coñecida a clásica distinción dialectal por parte do relixioso de Toén dun galego setentrional 
e dun meridional, que é, aínda que imprecisa, a primeira de todas cantas houbo aplicadas ao galego; pois ben, o maxisterio de Saco é evidente na súa total asunción por parte de Ballesteros cando dedica unhas palabras ao variacionismo xeográfico do idioma:

Una de las diferencias que separan los sub-dialectos gallegos es la $n$ en lugar de la $u$. El sub-dialecto septentrional dice hirmán, man, chan, y los plurales en uns, cans; mientras que el meridional prefiere decir hirmau, mau, chau ó chao, us, cas (CPG, I, 38, nota 1).

Un segundo e último exemplo da preitesía científica de Ballesteros en relación coa obra de Saco é o que se pode expor a respecto do dígrafo $<n h>$ para a representación da nasal velar, xa que di o autor da Gramática gallega:

La $h$ de unha y sus compuestos algunha, ningunha, representa la pequeña aspiración ó esfuerzo que es preciso hacer para impedir que la n forme sílaba con la $a$. Tiene el mismo oficio que el espíritu suave de los griegos, que impedía que la vocal inicial de una palabra se juntase en la pronunciación con la letra final de la palabra anterior (Saco Arce 1868: 26, nota $a$ ).

E repárese no que José Pérez Ballesteros, case con idénticas palabras, comenta sobre o antedito dígrafo, en que se fica ben explícita a súa fundamentación en Saco Arce:

La $h$ de unha, algunha, ningunha, representa la pequeña aspiración que es preciso hacer para impedir que la $n$ forme sílaba con la $a$. Hace el oficio del llamado espíritu de los griegos, que impedía que la vocal inicial de una palabra se juntase, en la pronunciación, con la letra final de la palabra precedente $(C P G, \mathrm{I}, 57$, nota 2$)$.

Mais a obra mesmo ultrapasou as propias fronteiras do país, xa que serviu de base a unha considerábel parte da romanística para o seu achegamento ao galego ou mesmo como información básica en relación a este. Neste sentido, é significativo que o apéndice de J. Cornu á súa obra Grammatik der Portugiesieschen Sprache, dedicado á nosa lingua e que foi publicado en varios números do Boletín de la Real Academia Gallega ao longo de 1906, se basease precisamente na Gramática gallega de Saco Arce; así o declara este investigador, mercé á tradución que fixo da súa obra Fernando Martínez Morás: "he tenido en cuenta la excelente Gramática Gallega de Juan A. Saco Arce, publicada en Lugo en 1868” (Cornu 1906: 7). Así

9 Con todo, tamén sinala outras fontes de información lingüística, xa que algúns "preciosos datos suplementarios me los proporcionó la lectura de considerable número de modernos textos gallegos, publicados en su mayor parte, en la Biblioteca Gallega" (Cornu 1906: 7). 
pois, estas anotacións referidas a Pérez Ballesteros ou a Cornu poden dar idea de que xeito e por que persoas eran manexadas, lidas ou coñecidas as primeiras gramáticas feitas para o galego: posibelmente, por un número máis ben reducido de eruditos, estudiosos ou curiosos.

O grao de alfabetización tamén debeu de xogar aquí un papel de importancia, pois os índices de persoas que non sabían ler nin escribir eran certamente altos. Isto, unido a que o galego estaba ausente en determinados ámbitos, pode explicar o escaso ou nulo coñecemento das obras de certas épocas. De igual xeito, ese mesmo número reducido de eruditos, ilustrados ou estudiosos das particularidades da cultura e da lingua galegas era o único que podía acceder a comentarios como este anónimo, aparecido no rotativo decimonónico pontevedrés El Buscapié (nº.93, 8.2.1868), onde se subliña o acerto da publicación de El habla gallega de Cuveiro Piñol:

la obra del Sr. Cuveiro tiene una importancia de primer orden, porque mientras tanto carezca nuestro país de una historia y de una gramática escritas, con razón nos tendrán en menos Cataluña, Vizcaya y Asturias que tanto cultivan su lengua y literatura provinciales [...]. No dude, pues, el Sr. Cuveiro, que á los ojos de todas las personas que en algo aprecian las letras de España tendrán mérito sus trabajos, y de su afición á estos estudios nos prometemos que en esta ocasión tendrá El habla gallega un hábil apreciador de su estructura, sus reglas y vicisitudes por que ha pasado (en Hermida 1992a: 95-96).

Certo é que determinada sorte de traballos científicos, como aínda hoxe se pode verificar, corresponde a un número de lectores e lectoras notabelmente pequeno, mais o chamativo, na nosa opinión, é que unha grande parte de escritores ou escritoras obviou eses traballos de gramática galega, non lles facendo grande caso ás indicacións que aparecían nas obras máis representativas. Esta situación pode verse explicada polas circunstancias históricas e políticas que condicionan a vida do país nos séculos XIX e XX e, no referente á segunda destas centurias, por un hiato político, social e cultural denominado Guerra Civil e pola súa ampliación de tres anos a corenta invernos de prohibicións, de medos, de represión e de falta de interese oficial por algo como o noso idioma.

Isto non é óbice, con todo, para que algúns autores do XIX perciban como rexionais ou dialectais determinadas formas, e mesmo para que aparezan críticas por se empregaren varias desas solucións. Hermida (1992b: 195) salienta, a este respecto, como as obras de escritores nados na Galiza occidental, como Rosalía de Castro ou Eduardo Pondal, chegan a influír en autores doutras rexións do país. O feito de se rexistraren formas características de certas rexións da Galiza en autores que non naceran nesas zonas é denominado por Fernández Salgado / Monteagudo Romero (1995: 134) "interdialectalismo", que é, de acordo con estes investigadores, "predominante nas obras literarias" de finais do século XIX. E Hermida (1992b: 195) 
subliña inclusive como, a se basear en artigos aparecidos na prensa da altura, algúns literatos eran cuestionados por utilizaren as formas típicas da súa área; tal era o caso de Saco Arce, poeta a quen El Heraldo Gallego lle critica que as súas composicións estean no galego ourensán. Porén, tales apreciacións non se van atestar até aos anos finais da devandita centuria, e, aínda se documentando, non constituíron un impedimento serio para que a maior parte dos textos literarios reflectise resultados dialectais, populares etc., isto é, para que os escritores e escritoras usasen aquilo que consideraban máis acaído.

\section{Escuálido rigor científico}

Se certo é, como indicabamos no parágrafo anterior, que a natureza dalgunhas obras determina un público lector en número reducido, é igualmente verdade que a calidade dun traballo pode determinar a súa escasa aceptación ou socialización. Isto enlaza con outra característica da tradición gramatical galega no seu conxunto, como é a súa escasa valía científica, e semellante trazo caracterizador pode estar detrás desa falta de socialización. Efectivamente, deixando de parte as obras publicadas na segunda metade do século XX e nos primeiros anos da seguinte centuria, chama a atención a escaseza de fundamentación filolóxica de El habla gallega de Cuveiro Piñol, dos Compendios de Mirás e de R. A., dos Elementos de Valladares, da Filología de la lengua gallega de Santiago y Gómez e mesmo tamén da Gramática de Carré Alvarellos. Sobre este particular, o profesor Freixeiro Mato (1998: 32) subliña o "pouco relevantes" que son os estudos lingüísticos da nosa tradición gramatical, ao paso que tamén pondera, na liña do que apuntabamos máis arriba, o feito de seren "historicamente escasos"10. Na mesma liña, Carballo Calero (1979: 30) indica que as nosas gramáticas modernas son "obra de aficionados o eruditos sin formación lingüística sistemática, o de filólogos de formación anticuada".

Cousa distinta é a Gramática de Saco Arce, pois serviu durante moito tempo como única referencia rigorosa para aquelas persoas que se interesaban polas características gramaticais do galego. Aínda que ficou moi superada polos títulos máis recentes ${ }^{11}$, o certo é que, mesmo na actualidade, é de obrigada consulta para termos unha

${ }^{10}$ Véxase tamén Freixeiro Mato (2002: 108) cando, agora máis concretamente, se refire ás gramáticas do primeiro terzo do século XX: "No ámbito editorial as publicacións de gramáticas e dicionarios continuaron o camiño emprendido no XIX, sen chegaren a superar neste primeiro terzo do século as dúas obras máis importantes: a gramática de Saco Arce e o dicionario de Valladares".

11 Pódese afirmar que, en xeral, o "reinado", se se nos permitir o coloquialismo, da obra de Saco Arce finaliza cando Carvalho Calero publica a súa Gramática, que chegou a ter sete edicións. A este respecto, Mariño Paz (2002: 78) sinala que a "Gramática elemental del gallego común, como instrumento posto ó servicio da docencia de lingua galega que se impartiu na Universidade de Santiago de Compostela durante a segunda metade da década dos anos sesenta e a década dos setenta, foi transformándose e ampliándose conforme as mudanzas dos tempos e as novas demandas docentes así o esixían”. 
idea de como podería ser o galego de finais do XIX, nomeadamente a variedade de Ourense, a súa cidade natal. El foi o primeiro que tentou sistematizar, cun éxito notorio a termos en conta traballos contemporáneos e mesmo posteriores, as particularidades gramaticais do noso idioma e, certamente, algúns dos datos que nos proporciona non deixan de nos parecer curiosos, aínda que conteña informacións que hoxe sabemos inadecuadas, inacaídas ou incorrectas.

Unha boa parte das gramáticas e dos traballos posteriores á de Saco Arce ten a súa inspiración nesa obra, aínda que os resultados non estean en moitos casos á altura das fontes orixinais. Do traballo de Santiago y Gómez, por exemplo, afirma Carballo Calero (1979: 34), facendo súas as palabras de Rohlfs, que, coa excepción do que tira de Saco, nada hai de interese nese contributo absolutamente diletante e retrasado desde o punto de vista científico. Non se lle dedican mellores xuízos a Lugrís Freire, pois o mesmo Carballo Calero (1979: 34) matiza que se se suprimir o que o mariñán traduciu do presbítero ourensán "bien poca cosa queda”, o que vén coincidir coas impresións de Santamarina (1974: 194), quen afirma que a gramática de Lugrís non é senón unha tradución para o galego da obra de Saco.

Máis nunha ocasión, non se pode obviar o contexto da lingua a respecto da cualidade das súas gramáticas. Até non hai moitos anos, como é sabido, o galego estivo proscrito da universidade, de academias, do ensino básico ou medio, fóra, en fin, de todos os organismos e institucións en que ou ben se podía estudar a lingua en profundidade e sistematicamente ou ben era imprescindíbel ter un bo coñecemento dela para se expresar diante dun potencial alumnado ou público. A citación de Carballo Calero en que se sinalaba a escasa preparación da maior parte dos autores debe ser tamén posta en relación, pois, con estes factores de secular ausencia.

\section{Fonda pegada diglósica na maioría delas}

Estando o país nunha situación de conflito lingüístico e sendo esa problemática doadamente encadrábel baixo a neborenta caracterización da diglosia, é lóxico presupormos que tales coordenadas sociolingüísticas vaian aparecer reflectidas nas obras que estudan unha das linguas en conflito, neste caso a galega. Podemos afirmar, pois, que a maior parte dos traballos que conforma o noso patrimonio científico no tocante a investigación e descrición do idioma ten como principal trazo idiosincrático ese transfondo diglósico, e constitúe un groso óleo que se deixa entrever nos seguintes factores:

1. En primeiro lugar, quitando os traballos aparecidos desde a publicación da Gramática Galega de Álvarez / Regueira / Monteagudo (1986), as máis das gramáticas están escritas en español, coas honrosas excep- 
cións de R. A. (1919), que é o primeiro título redixido en galego, e de Lugrís Freire $(1922,1931)^{12}$. Semellaba non valer o noso idioma para se describir a si propio, como tampouco parecía adecuarse para se empregar en textos que non fosen de carácter literario, nomeadamente os líricos, de índole ensaística (coa excepción da prosa de Nós) ou doutro tipo de modalidades compositivas que se non axustasen a aquilo en que o galego resultaba ser "máis acaído".

2. E en segundo lugar, falta na maioría das obras reflexión lingüística para ser logo aplicada á lingua do país, tal e como é habitual nas nacións e estados do noso contorno. Coa excepción, máis unha vez, dos traballos aparecidos desde fins do século XX até á actualidade, as gramáticas galegas evitan calquera tipo de teorización gramatical pois, implicitamente, esa xa se facía en español, de modo que se limitan a dar conta das especificidades do noso idioma que non coinciden ou que se non achan na lingua castelá. Así as cousas, o discurso gramatical galego nos seus comezos case pode ser denominado "comparativista", xustamente por esa constante equiparación ou confronto co español.

A teor, por tanto, destes dous fenómenos, a maior parte das gramáticas galegas non estaba pensada desde e para o galego, mais desde o español e coas metas científicas marcadas neste mesmo idioma. Tan raro como pode ser hoxe en día unha gramática inglesa pensada para ingleses mais escrita en xaponés ou en gaélico e incidindo nos aspectos que non coinciden con estas dúas linguas, era habitual que os traballos de filoloxía galega fosen redixidos no idioma que axía como teito cultural e que se prestase especial atención aos asuntos que non achaban un correlato exacto nesa lingua considerada "superior". Como sinala Freixeiro Mato (1998: 33), "pódese afirmar que o discurso gramatical galego foi construído en comparación, contraste ou oposición constante á lingua dominante politicamente". Vexamos algúns exemplos deste fenómeno tirados da propia tradición gramatical galega, como o seguinte, de Juan Cuveiro Piñol; encóntrase ao comezo do seu traballo e fala do alfabeto galego e da súas particularidades de pronuncia:

El alfabeto gallego consta de las mismas 28 letras del castellano, cuya pronunciación alfabética es enteramente igual á la de este idioma [sic], con la sola diferencia de que los gallegos las hacen indistintamente masculinas o femeninas, vr. Gr. Un a unha a, etc. (Cuveiro Piñol 1868: 1).

12 Afirma sobre este particular Fernández Salgado (2000: 195) que o "galego, para Carré e para Lugrís debe estudiarse en galego sen necesidade de comparacións nin referencias a outras linguas", o que supón certamente unha destacábel particularidade con relación ás gramáticas anteriores e mesmo a algunhas das posteriores. 
Cunha preparación filolóxica moi superior á de Cuveiro, o presbítero Juan Antonio Saco Arce, a comentar os procesos de formación de palabras mediante o procedemento da sufixación por derivación, afirma o que segue:

AZO, OTE, ON. -Aumento de la significación del primitivo. Son, como en castellano, las terminaciones de los aumentativos; pero con la diferencia de que aquí los sustantivos de terminación femenina, toman al hacerse aumentativos, la desinencia feminia ona, en vez de la masculina on que en el castellano, menos lógico, atribuye a muchos de ellos (Saco Arce 1868: $45)$.

Á súa vez, José de Santiago y Gómez, falando dos trazos xerais do verbo e en especial das súas conxugacións, apunta na súa obra:

La conjugación gallega concuerda en sus rasgos generales con la castellana, y distingue como la latina tres personas en dos números; abandonó enteramente las desinencias medio pasivas (Santiago y Gómez 1918: 191)

O coruñés Leandro Carré Alvarellos, vestido co disfarce que lle proporcionan as siglas R. A. (Ramón Alvariño), indica das regras ortográficas do noso alfabeto o seguinte:

As letras do alfabeto gallego teñen na súa maioría a mesma pronuncia e valor que no idioma español, pol-o tanto soilo falaremos d'aquelas que teñan algunha diferencia ou as que poidan dar lugar a dúvidas (R. A. 1919: 34).

Para o mariñán Manuel Lugrís Freire, as cuestións que se debían salientar no tocante ao xénero nos nomes é a súa inexacta correlación entre o galego e o español:

Hai moitos nomes que son femeninos en castelán, e na nosa fala son sempre masculinos: a saber: o costume, o cume, o cal, o celme, o leite, o lume, o couce, o sangue, o mel, o nariz, o víspera, o sal, o cuspe, o berce, o sucre (Lugrís Freire 1931: 25).

O miscelánico traballo de Antonio Couceiro Freijomil contén unha parte dedicada a tratar a ortografía que el considera máis adecuada. Nese apartado, a falar da supresión de sons na lingua popular, maniféstase con estas palabras:

La pérdida de la $n$ en el primer caso es más bien un vicio de pronunciación, al que tampoco es ajeno el castellano, según puede observarse en este ejemplo: te(n)me el lápiz (Couceiro Freijomil 1935: 205). 
Outra vez, no caso do autor xa citado máis arriba, Leandro Carré Alvarellos, un asunto que lle chama a atención dos nomes galegos canto á súa formación de plural é o seguinte:

Número es el accidente gramatical que indica si se habla de uno o de más de uno. Los números en gallego, como en castellano, son dos: singular y plural (Carré Alvarellos 1967: 47).

E mesmo o profesor Ricardo Carballo Calero non puido ser alleo a esa situación diglósica, como se desprende destas súas palabras dedicadas ao pronome relativo $\mathrm{cal}^{13}$ :

Cal 'cual', plural cais 'cuales', no admite flexión genérica. Se usa más como sustantivo que como adjetivo. En función de relativo va precedido del artículo determinado. Corresponde en su uso, de modo completo, al castellano, por lo que excusamos ejemplos (Carballo Calero 1979: 205).

En fin. Coidamos que estes exemplos ilustran ben ás claras a dependencia tanto no que se refire á lingua utilizada maiormente como ao transfondo diglósico, que se materializa sobremaneira na constante e recorrente comparación da casuística gramatical do galego coa do español.

\section{Carácter prescritivo}

Aínda que cada obra é singular en si propia, dáse unha outra característica no discurso gramatical galego, que consiste no carácter normativo da maioría das obras. Antes de máis, convirá clarificarmos que non todas posúen o mesmo grao desta particularidade, mais é notábel, insistimos que con diferenzas de intensidade, esa pegada prescritiva. Isto tórnase lóxico de comprendermos a repararmos no abandono oficial en que se achaba a lingua no momento de saír do prelo a maioría dos estudos, a que xa fixemos alusión máis arriba, xa que ningún organismo, público ou privado, se ocupou de analizar o galego. É doado de entendermos, pois, que se fixese necesario contar cun modelo de lingua escrita que puidese servir como guía ou como solución a diversos problemas con que se ía encontrando a xente que protagonizaba o noso particular "renacemento" literario. Á falta dun modelo de lingua oral e escrita común que escolmase as diferentes falas dialectais, uníase o polimorfismo e a heterografía que vai caracterizar os nosos textos literarios do XIX e do $\mathrm{XX}^{14}$.

13 O humanista ferrolán, como indica Mariño Paz (2002: 75-77), explicaría en varias ocasións esa dependencia do español acudindo á época (o franquismo), ao público lector (xente que xa coñecía a gramática castelá e que podía achegarse á galega desde os puntos en común entre ambas) etc.

14 Situación que chega aos nosos días en forma dunha norma ortográfica e morfolóxica, mais con carencias noutras compoñentes da descrición gramatical. Álvarez Blanco (1994: 19-20) sinala, sobre este 
Porén, á parte desa vontade normativa, os coñecementos existentes sobre o galego, que comezan nestes anos a súa particular singradura nun bravo oceano, non foron quen de marcaren fronteiras precisas entre algúns eixos elementares da especulación científica dedicada á lingua, como as nocións de común e dialectal, de estilo coidado e estilo informal, de correcto e incorrecto etc. Tales nocións, hoxe fundamentais para unha análise gramatical rigorosa, aparecen con frecuencia abretemadas nas obras do século de que estamos a falar e, non raro, aparecen con frecuencia casuísticas morfolóxicas de certa transcendencia xeográfica a carón doutras minoritarias ou laterais (adverbios deícticos tipo eiquí xunto a aquí en Saco Arce), españolismos ocorrendo ao lado de formas autóctones (como é o caso dos tempos compostos con haber en Cuveiro Piñol) etc.

Ás veces, o sentido da orientación dos gramáticos consagrábase a desterrar españolismos da nosa lingua, como amosa a seguinte citación de Manuel Lugrís Freire, onde se comentan "algunhas particularidades do réxime do verbo"; seguindo moi de cerca os exemplos que expuña en pleno Rexurdimento o ourensán Saco Arce, indica a respecto de certas construcións pronominais o que segue:

Empréganse en galego como intransitivos, en vez da forma refleisiva, os verbos cando a sua acción se refere ao suxeto, v. g.: "O reló xa parou". "O fidalgo de Pazos xa emprobeceu". "A roupa xa exoitou". E non debera dicirse: "O fidalgo xa se emprobeceu”. “O reló xa se parou” (Lugrís Freire 1931: 98).

Con todo, outras veces o carácter prescritivo que se revela nalgúns títulos insiste en condenar trazos xenuinamente galegos, o que debe ser contemplado desde a falta de tradición filolóxica no momento e desde a irregular formación dos diferentes autores; pertencen a Marcial Valladares (1970: 52-53) as seguintes palabras, destinadas a proscribiren o infinitivo flexionado.

Esta conjugación, especie de futuro imperfecto de subjuntivo, creémos que ni es precisa, ni debe aconsejarse [...]. Quitemos á los infinitivos de estos verbos su terminación en y los ejemplos aducidos dirán, significarán lo mismo, pero de una manera más pura, más correcta.

E, a se referir á forma tèren, que aparece nun cantar tradicional publicado nun xornal, conclúe:

particular, que "só se estableceu ata o de agora unha Normativa ortográfica e morfolóxica, non sintáctica, e polo xeral predícase que son correctas tódalas variantes que se poidan describir dentro dos límites da gramática do galego". 
Aquí la persona agente es el pronombre eles que se supone en lugar de donos, ejerciendo su acción sobre el infinitivo ter, que maldita necesidad tiene de la adición en, para significar lo mismo; solo, si, para llenar el verso.

Tamén non teñen perda os seus comentarioas sobre as construcións transitivas direccionais formadas co verbo ir + prep. en (Vai na vila; Van na casa dos avós etc.), xa que as declara como incorreccións sempre condenábeis; o seguinte fragmento rexeita explícitamente esa particularidade lingüística do galego:

Los gallegos, si no todos, muchos decimos: vai á Santiago; vai à vila; vai à feira; vai à romaría; vai ò muíño [...]. Y también vai en Santiago; vai n’a vila; vai n'a feira; vai n'a romaría; vai n'o muíño. Lo primero, supone que la persona, de quien se hable, piensa ir, salir, ó camina á uno de los puntos indicados; pero que no há llegado todavía: lo segundo, supone que há llegado ya, que está allí. En el primer caso, no hay defecto del lenguaje; en el segundo si lo hay y consiste en tomar un tiempo por otro y una preposición por otra; pues si la persona, de quien se hable, há llegado á uno de dichos sitios, si está allí ¿como hemos de poder decir que vá, cuando este vá, ó vai es tiempo presente? El pretérito, ó pasado, es el tiempo que debe usarse y decir há ido, no en, sino á, preposición que en este caso rige el verbo ir. Mas, como el gallego, por carecer de tiempos compuestos, no tiene equivalente para há ido y, de emplear el pasado perfecto foi $=$ fue, dá á entender que la persona há regresado, lo que no es su ánimo significar; de ahí que lo mejor, en casos tales, es valerse de otros verbos, decir, por ejemplo, marchóu á...; saèu pra... (Valladares 1970: 111).

De cando en vez, algúns autores, a se guiaren pola procura da enxebreza idiomática e polo diferencialismo, incorreron na defensa de trazos de marcada autoctonicidade mais en usos agramaticais. O primeiro terzo do século pasado caracterizouse, no tocante ao modelo lingüístico, pola constante priorización de todo aquilo que fose diferencial en relación ao español. O tradicional recurso da interpolación gramatical, subsecuentemente, non resultou indiferente para certos gramáticos, que o contemplaban como unha estrutura morfosintáctica marcada positivamente por se non atestar en castelán. Esa procura do xenuíno, do enxebre, foi a causante de que se empregase en casos en que o pronome átono aparece en posición inicial absoluta e, tamén, foi o motivo de que Lugrís Freire (1931: 87-88) se referise a dita construción coas seguintes palabras, ponderando, xunto a estruturas lexítimas, outras agramaticais:

"Que me non queira; $o$ non vin; non se foi nin pensa en se marchar". Esto resulta mais conforme cô verdadeiro xeito galego que as formas que adoita empregar as xentes das vilas e moitos escritores dicindo: "Que non me queira; non- $o$ vin; pensa en non marcharse".

Así mesmo, non están sen exemplo tentativas de escolla dalgunha das diferentes solucións dialectais, que non chegarían a callar por, entre outros motivos, a anteci- 
tada falta de socialización. Constitúe un testemuño deste fenómeno a seguinte citación de Saco Arce (1868: 32), quen se declaraba, talvez pola súa procedencia ourensá, partidario do que que era (e aínda hoxe é) habitual na súa rexión no referente á formación do plural das palabras terminadas en $-n$ :

La combinación $n s$ no es sin embargo muy eufónica, y no convendrá prodigarla. El gallego, por punto general, la repugna.

De igual modo, debemos facer referencia aos pretéritos dos verbos regulares da segunda conxugación para a P2 na súa vocal temática, xa que o clérigo de Toén vai concederlle certa preferencia á solución máis innovadora-eche $(s)$ en detrimento da máis conservadora -iche(s) (Saco Arce 1868: 76):

Las dos formas de esta persona en la segunda conjugación (bateche, batiche), pertenecientes á las dos principales ramas subdialécticas del gallego, pueden usarse indistintamente; sin embargo, la primera es más regular, pues sigue más exactamente la analogía del verbo bater, cuya conjugación tiene la $e$ por vocal dominante. Ademas, la desinencia iche ó iches se confunde con la de idéntica persona de la tercera conjugación.

No entanto, predominando un certo carácter prescritivo ao longo da nosa tradición gramatical, tamén non faltan casos en que esa vontade de prescrición desaparece totalmente, de forma que se pode afirmar que hai ocasións en que se obvia dita tendencia normativa. Así se desprende, por exemplo, do seguinte comentario de Cuveiro Piñol (1868: 8), cando, desenvolvendo o número, proporciona certas informacións de carácter dialectal indicando que ningunha delas resulta inapropiada:

El plural de los nombres gallegos, tenga el singular la desinencia que quiera, no se forma como en castellano [...]: manos, mas, mans, maos y maus según dijimos en el prólogo [...]; manzanas, mazás, manzás y mazáns; ciudadanos, ciudadaos, ciudadás y ciudadáns [...] según las diferentes comarcas, pero que cualquiera de ellos no disuena.

Canto a institucións como a RAG, ou ben non existían ${ }^{15}$ no momento de seren redixidas algunhas gramáticas (Mirás, Cuveiro, Saco Arce ou Valladares), ou ben,

15 Para o proceso que desembocou na creación da Real Academia Galega e na primeira época da institución, presidida por Manuel Murguía, véxase López Varela (2001), quen se refire ás orixes do devandito proceso nos seguintes termos: "Esta inquietude [a da creación da Real Academia Galega] comezou a mediados do século XIX ou posibelmente antes, ao abeiro da creación da Academia Española a principios do XVIII, pois algunha elites ilustradas do país gustaban de contar cun organismo que recollese esas inquietudes" (López Varela 2001: 13). O investigador arteixán pondera, así mesmo, que os seus fins eran a elaboración dun diccionario e dunha gramática que "deran unidade ao idioma" (2001: 121-136). 
aínda xa existindo, demostraron a súa total ineficacia no sentido de non dotaren a lingua de estudos desta índole. Houbo autores que puñan nas mans da creación dunha institución a tarefa de harmonizar todas as variantes dialectais coa finalidade de se elaborar unha norma común. En 1890, no prólogo ao libro Brisas gallegas, de M. Lois Vázquez, este expuña as súas impresions ao respecto:

Ocasión tiven d'ouservar ben de cerca a notabre diferencia de falar o gallego en Santiago, Pontevedra, Vigo y-outros puntos d'a costa ô que se fala n'a provincia d'Ourense. A min nunca me deprenderon a dicir chan, man, faser, sigarro y-outras palabras pol-o estilo, hastra que cheguei ôs sitios arriba citados; e por eso me queixo qu'entre unhos y-outros traballos esquirtos en gallego se alcontr'un c'o imperdoabre desacordo n'unhas mesmas palabras en vez d'iren n'a mais perfeut'armonía.

¿Pode esto correxirse co-a non interrompida pubricación de peródicos e libros?

Non.

Si o cáncere corrosivo que tira contr'a estabridá d'o noso idioma non se corta de raíz, estonces sempre será perdido.

¿E como se podría levar á cabo tan laudabre como patreóteca empresa?

Co-a ACADEMIA GALLEGA $(B G 9)^{16}$.

O único traballo de antes da Guerra Civil que a susodita institución puido dar a lume foi, como é sabido, o Diccionario gallego-castellano (1913-1928), que ficou inconcluso na entrada cativo por falta de orzamentos que puidesen subsidiar a súa publicación.

\section{Descontextualización}

Tarde se incorporou o galego á literatura filolóxica e isto determinou as tendencias que se observan dentro das súas gramáticas no que se refire a escolas lingüísticas. A demora no aparecemento das primeiras obras se confrontadas coa situación doutras linguas é o que explica, pois, a súa descontextualización a respecto do que se viña facendo noutros países da Europa occidental. Como indica Henríquez Salido (1986: 447), cando Mirás publica o seu Compendio, en 1864, había xa moitos anos que Bopp, Grimm ou Humboldt levaban traballando noutros ámbitos cunha metodoloxía superior á que adopta o noso primeiro gramático, ao paso que na segunda metade do XIX tamén son editados algúns dos contributos de Schleicher ou Hermann Paul, hoxe xa clásicos. E a Galiza non podía dedicarse ao estudo do sáns-

16 Texto tamén escolmado por Samartín Rei (2002: 110-114), autora que estuda e que fai unha selección en clave sociolingüística dos prólogos galegos entre 1863 e 1936. 
crito, ás variacións lingüísticas históricas ou mesmo a comparar as linguas indoxermánicas cando o seu idioma comezaba a ser obxecto de reflexión con séculos de retraso. Saco Arce, no entanto, amosa coñecer en certa medida o que se estaba a facer na Europa, baixo as orientacións do comparativismo e do historicismo, e así o parece insinuar, como indica Henríquez Salido (1986: 453), cando o presbítero, centrándose no español, indica a conveniencia de poder confrontar varias linguas:

No es mi ánimo con esto excitar al abandono ó descuido del majestuosos idioma castellano, el cual lejos de perder, ganaria mucho con el estudio y comparación de los dialectos afines (Saco Arce 1868: VII).

Doutra parte, o que noutras linguas é produto da reflexión desde diversas perspectivas de análise como froito dunha tradición secular, no noso caso é observábel un duplo predominio canto á abordaxe do fenómeno lingüístico: por un lado, as primeiras gramáticas están dentro do que poderiamos denominar, cun título moi amplo, Gramática Tradicional, aínda que o resultado non chegue adoito a traballos rigorosamente científicos. Por outro lado, é notábel nos últimos tempos unha tendencia cara á escola estrutural-funcionalista, o que é lóxico de explicar a termos en conta o predominio desta corrente no Estado español e en especial desde que Emilio Alarcos Llorach axiu de introdutor dese marco teórico.

Mais, con independencia da valía e do adecuado que poida resultarnos o funcionalismo ou o estruturalismo, e con independencia tamén do suceso ou insuceso de diferentes filosofías científicas para o estudo da lingua, faltan no galego obras xerais que partan doutros marcos teóricos. Non hai, pois, como pode haber no inglés, no francés ou noutros idiomas do noso contorno internacional, gramáticas dependenciais (seguindo os modelos de Tesnière, Helbig, Wotjak, Vilela etc.), xerativas nas súas diversas concepcións e reformulacións (baseándose en Chomsky, Lakoff, McCawley etc.), neofuncionalistas ou sistémicas (que subcribisen os postulados de Givón, Foley, V. Valin, Halliday etc.) etc. E este será un labor que terá de ser desenvolvido polos estudiosos da gramática galega se se quixer normalizar todo o referente ao idioma do país, de que a súa tradición filolóxica é outro campo de traballo.

Cando ponderamos a antecitada descontextualización, non estamos, obviamente, a deixar de lado contributos modernos realizados desde postulados teóricos distintos do estruturalismo ou do funcionalismo, e neste sentido son de obrigada cita, entre outros, os traballos de Prieto Alonso (1986) ou de Dubert García (1999). Ora, o primeiro como o segundo, proporcionándolle ao idioma galego novas perspectivas de estudo, non foron concibidos como gramáticas, mais como senllos monográficos consagrados respectivamente á sempre recorrente disposición dos clíticos no galego e ás particularidades da lingua oral compostelá. Tampouco pretendemos secun- 
darizar a interconexión que nos últimos anos se está a producir entre os distintos marcos teóricos de abordaxe, no sentido de que a adopción dun modelo determinado puider marxinalizar achegas válidas elaboradas baixo outra corrente lingüística ou mesmo baixo outras ciencias. Desta maneira, Moure (2000: 48) salienta atinadamente que na actualidade "se algo caracteriza a investigación linguiística é a proliferación de enfoques conectados, a perspectiva interdisciplinar", o que está detrás de modernas abordaxes cal a neurolingüística, psicolingüística, lingüística cognitiva etc.

\section{Presenza de partes circunstantes}

Unha das cousas que máis chama a atención ao público lector actual da nosa tradición gramatical, e mesmo ao alumnado que manexa as súas obras ao principio das súas pesquisas, está directamente relacionada con determinados capítulos ou apartados que hoxe non costuman figurar neste tipo de traballos. De feito, a primeira gramática que non inclúe nada que non estea directamente relacionado coa descrición lingüística é o traballo de Álvarez / Regueira / Monteagudo (1986), que prescinde totalmente de certos aditamentos ou acrecentamentos tales como os nomes dos días da semana e dos meses do ano, certas escolmas literarias, vocabularios de diversa índole, tentativas de clasificación e referencición dialectais etc.

É certo que existen na actualidade diferentes consideracións sobre que partes integran a gramática e cales outras non pertencen ao seu obxecto de estudo; lembremos que a gramática de Carballo Calero incluía un capítulo destinado á historia externa da lingua, ás súas variedades dialectais ou á súa (daquela) escasa bibliografía existente. Con efecto, pódese discutir (e consecuentemente concordar ou discordar cos postulados do humanista ferrolán) se nun manual desas características tales capítulos teñen cabida, e, suscribíndoos ou non os considerando, pódese tamén explicar polas circunstancias da xénese da obra, nuns momentos en que o galego comezaba a ser estudado con rigor e en que era preciso contar cunha obra actualizada que se non limitase unicamente a facer unha descrición do seu funcionamento fonético, fonolóxico ou morfosintáctico. Mais, ao fin e ao cabo, esas indicacións bibliográficas comentadas, a súa apreciación dos fenómenos máis salientábeis do variacionismo xeográfico no noso país ou mesmo esas orientacións para a historia da lingua están relacionadas co propio idioma, aínda que saibamos que constitúan outras disciplinas útiles no dominio da lingüística.

Ora, o feito de que aparezan escolmas poéticas, tabelas con nomes galegos cos seus correspondentes españois, os días da semana ou dos meses, ou inclusivemente artesanais vocabularios como anexos ás gramáticas, está, hoxe en día, tan fóra de lugar como se nunha obra moderna desas características se eliminar o capítulo dedicado ao verbo, ao nome, ao CI etc. Máis unha vez, ese carácter miscelánico é explicábel 
polas circunstancias históricas que determinaron a redacción e a preparación lingüística do autor, non se perpetuando nos nosos días: nin en Álvarez / Regueira / Monteagudo (1986), como dixemos máis arriba, figura esa sorte de apartados, nin Costa / González / Morán / Rábade (1988) os inclúen, nin Freixeiro Mato (1998, 1999, 2000; 2001; 2003) se ocupa deles na súa obra, nin tampouco son considerados por Álvarez / Xove (2002). Non aconteceu así, como indicabamos, cos outros autores do século XIX ou do XX, como o ben verifican algúns casos que brevemente imos expor como exemplos ao respecto. En todos eles parece que se pretende proporcionar, segundo o noso punto de vista, unha perspectiva do galego máis ampla alén da estritamente lingüística, tal vez coa vontade de ilustrar, exemplificar ou dignificar aquilo que se pretendía describir ${ }^{17}$ ou mesmo de prescribir certo léxico ou nomes propios erosionados pola presión do español.

No caso do Compendio de Mirás o seu título fala xa de si propio e indica o que se inclúe na obra: Compendio de gramática gallega-castellana, con un vocabulario de nombres y versos gallegos y su correspondencia castellana, precedido de unos diálogos sobre diferentes temas. Un grandioso poema de 100 octavas titulado "La creación y la redención. Un extracto de Fábulas de los mejores fabulistas así como algunas del autor. Pouco de compendio gramatical ten este traballo a repararmos en que o contido estritamente lingüístico ocupa ben poucas páxinas, xa que logo figura o antedito e minúsculo vocabulario (páxs. 39-50), seguido dunha listaxe de verbos traducidos para o español (páxs. 51-56) e concluído cunha sorte de diálogos de marcado carácter colonialista, alén doutras composicións literarias de escasa valía artística.

Saco Arce non foi alleo á incorporación de aditamentos á súa gramática, aínda que esta sexa, en rigor, a primeira obra realizada con seriedade sobre a nosa lingua. Deste modo, no apartado dos "Apéndices" (Saco Arce 1868: 261-313) figuran unha selección de refráns galegos e unha serie de textos literarios dos autores da altura, tales como Rosalía de Castro, Eduardo Pondal, Alberto Camino, Xoán Manuel Pintos, Marcial Valladares etc. Unha das diferenzas que presenta en relación a Francisco Mirás é a maior cualidade literaria dos textos que se publican, o que é coherente coas dimensións científicas de cada traballo respectivo e, quizá, coa circunstancia de o clérigo ourensán se dedicar igualmente á composición na nosa lingua; neste sentido, chegou a criticar o uso dos españolismos e popularismos que facían algúns autores e autoras do XIX e mesmo a pouca presenza de cultismos, sinais que revelan certa preocupación estética e artística (véxase Hermida 1992a: 105-111).

${ }^{17}$ O caso de textos poéticos que incluían algún apéndice sobre certos aspectos gramaticais non perseguen estas aparentes finalidades e a súa meta parece ser, inicialmente, outra ben diferente, como é a de facilitar a un público non afeito a ler en galego unhas indicacións elementais, sempre se tomando como referencia o español. É o caso, por exemplo, de Martínez González (1883) ou Cabo Pastor (1929), que findan dúas obras con esas básicas orientacións. 
O Compendio de Ramón Alvariño prescinde de calquera acrecentamento, o que é doadamente comprensíbel a repararmos na brevidade do seu traballo. Porén, non é este o caso de Manuel Lugrís Freire, quen non dubida en lle incorporar á súa Gramática do idioma galego unha serie de "Aditamentos" (1931: 113-120) dedicados á toponinima e antroponimia etc., unhas "Mostras literarias" (1931: 121-136) con textos de Florencio Vaamonde Lores, Euxenio Carré Aldao, Manuel Murguía, Castelao, Eduardo Pondal etc., e mesmo un "Vocabulario galego-castelán" (1931: 137-184).

Deixándomos a un lado a xa comentada obra de Carballo Calero (1979) e tamén o traballo de Couceiro Freijomil (1935), a derradeira mostra que citamos como exemplificación deses aditamentos é o de Carré Alvarellos (1967: 194-206) no que se refire ao variacionismo xeográfico da lingua galega, desenvolvido como “Capítulo XVII. Variaciones dialectales". É verdade que anteriores títulos xa incorporaran, con maior ou con menor fortuna a se basearen principalmente nas indicacións de Saco Arce, algunhas páxinas en que se consideraban certos fenómenos dialectais do idioma, cal Santiago y Gómez (1918: 267-272), quen, logo de defender unha tripla división do galego nas variedades que el denomina "berciana", "lucense" e "bracarense", se refire, como fixera o clérigo ourensán, á existencia dun galego "septentrional" e outro "meridional"18.

Mais, voltando á obra que comentabamos, e xa para irmos concluíndo, o que ten de particular esta aproximación de Carré Alvarellos é o feito de distinguir, indicando sempre a súa localización xeográfica mesmo por vilas ou aldeas, algúns dos trazos dialectais máis rendíbeis na literatura linguística galega dedicada á dialectoloxía, como poden ser os plurais das palabras acabadas en - $n$, as terminacións -án $/$ - $a$ o, diferentes formas pronominais e adverbiais, presenza e ausencia de seseo etc.

\section{Conclusións}

Estas son, grosso modo, as características xerais da nosa tradición filolóxica, explicábeis polo momento en que se publican as obras e polas circunstancias sociais, políticas, culturais e lingüísticas que determinan as épocas en que saen do prelo. E tamén son, ao mesmo tempo, características doutras linguas ou variedades lingüísticas así mesmo en situación de anormalidade social, como é o caso da primeira

\footnotetext{
18 Entre outros comentarios que fai Santiago y Gómez figura este, iustrativo da súa dependencia da obra de Saco Arce neste particular: "Como regla general establecemos que se observa en el lenguaje de los habitantes del Norte de Galicia, que propende al empleo de las vocales abiertas mientras que en el Mediodía son más cerradas. En el Norte se nota cierta predilección por la $n$, que los del Sur la convierten en $u$; el subdialecto septentrional dice: irmán, man, chan, y los plurales uns, cans, mans, mientras el meridional prefiere irmao, mao, chao, us, cas, mas" (Santiago y Gómez 1918: 269).
} 
gramática aragonesa, que foi publicada en 1977, aínda que chegou a ter varias edicións (a última é Nagore 1989). Nesta obra áchanse trazos comúns coa nosa tradición gramatical, como son, por exemplo, o feito de estar redixida en español, a circunstancia de que calquera comparación sempre se estabelece con esta lingua, a relevancia social e política do momento histórico en que se edita (dous anos despois da morte de Franco) etc.

Mais, retomando o tema que nos ocupa, e xa para rematarmos esta achega, abundantes ou escasos, diglósicos ou non, de maior ou menor rigor filolóxico, acertados nas súas impresións ou totalmente inacaídos, todos os traballos que vimos de comentar para o galego constitúen os alicerces o noso discurso gramatical. Sabéndomolos superados con moito polos títulos máis recentes, que, como dixemos serán obxecto de reflexións específicas noutro lugar, coidamos que se non debe renunciar a ese legado, por escaso ou irrelevante que pareza, e aínda menos nunha situación como a da lingua galega, en que continúan a existir baleiros importantes en determinados ámbitos da súa especulación e divulgación científica.

\section{Referencias bibliográficas}

Álvarez Blanco, R. (1994): “Gramática descritiva e gramática prescritiva”, Cadernos de Lingua, 10: 19-35.

Álvarez, R. (2001): "Fuco Gómez: Grafía galega, Habana 1927”, en Kremer, D. (ed.), Actas do VI Congreso Internacional de Estudios Galegos. Vol. I: 3-18 (A Coruña / Trier: Edicios do Castro / Galicien-Zentrum der Universität Trier).

Álvarez, R. / Regueira, X. L. / Monteagudo, H. (1986): Gramática galega (Vigo: Galaxia).

Barboza, J. Soares (1830) [1822]: Grammatica Philosophica da Lingua Portugueza ou Principios da Grammatica Geral Applicados á Nossa Linguagem (Lisboa: Typographia da Academia Real das Sciencias).

Bécares Botas, V. (ed.) (2002): Dionisio Tracio, Gramática. Comentarios antiguos (Madrid: Gredos).

BG = Lois Vázquez, M. (1890): Brisas Gallegas (Lugo: Gerardo Castro).

Cabo Pastor, F. (1929) [s.d.]: "Notas de gramática gallega", en Cabo Pastor, F., Versos gallegos (Cántigas e cousas d-a nosa terrra): 7-11 (Ferrol: Impr. El Correo Gallego).

Carballo Calero, R. (1979) [1966]: Gramática elemental del gallego común (Vigo: Galaxia). 
Cardoso, S. (comp. e org.) (1994): Historiografía gramatical (1500-1920). Língua Portuguesa-Autores Portugueses. Anexo VII da Revista da Faculdade de Letras do Porto (Porto: Faculdade de Letras do Porto).

Carré Alvarellos, L. (1967): Gramática gallega (A Cruña: Editorial Moret).

$C G$ = Pociña, A. / López, A. (eds.) (1993) [1992]: Rosalía de Castro. Poesía galega completa. I. Cantares Gallegos (Santiago de Compostela: Sotelo Blanco).

Cornu, J. (1906): "Morfología del gallego moderno" [tradución realizada por Martínez Morás da parte correspondente ao Apéndice á Morfoloxía do Portugués que aparece na segunda edición da Grammatik der Portugiesischen Sprache], Boletín de la Real Academia Gallega, 1: 7-9.

Costa, X. X. / González, M. A. / Morán, C. C. / Rábade, X. C. (1988): Nova gramática para aprendizaxe da língua (A Coruña: Vía Láctea).

Couceiro Freijomil, A. (1935): El idioma gallego. Historia, gramática, literatura (Barcelona: Casa Editorial Alberto Martín).

$C P G=$ Pérez Ballesteros, J. (ed.) (1979) [reimpr. facs. da edición de 1885-1986]: Cancionero Popular Gallego y en particular de la provincia de la Coruña por José Pérez Ballesteros. Con un prólogo del ilustre mitógrafo portugués Theóphilo Braga. 3 vols. (Madrid: Akal).

Cuveiro Piñol, J. (1868): El habla gallega. Observaciones y datos sobre su origen y vicisitudes (Pontevedra: Imprenta de José Antúnez y Cía).

Dubert García, F. (1999): Aspectos do galego de Santiago de Compostela. Anexo 44 de Verba (Santiago de Compostela: Universidade de Santiago de Compostela).

Feixó Cid, X. (2004): Gramática da lingua galega. Síntese práctica (Vigo: Xerais).

Fernández Salgado, B. (2000): Os rudimentos da lingüística galega. Un estudio de textos lingüísticos galegos de principios do século XX (1913-1936). Anexo 47 de Verba (Santiago de Compostela: Universidade de Santiago de Compostela).

Ferreiro, M. (1997): Gramática históirica galega. Vol. II. Lexicoloxía (Santiago de Compostela: Laiovento).

Ferreiro, M. (1999) [1995]: Gramática histórica galega. Vol. I. Fonética e morfosintaxe (Santiago de Compostela: Laiovento).

FN = Castro, Rosalía de (1982) [repr. facs. da ed. de 1880]: Follas Novas (A Coruña: Ediciós do Castro / Moret / Real Academia Galega).

Freixeiro Mato, X. R. (1998): Gramática da lingua galega. Vol. I: Fonética e Fonoloxía (Vigo: A Nosa Terra).

Freixeiro Mato, X. R. (1999): Gramática da lingua galega. Vol. II: Semántica (Vigo: A Nosa Terra). 
Freixeiro Mato, X. R. (2000): Gramática da lingua galega. Vol. III: Morfosintaxe (Vigo: A Nosa Terra).

Freixeiro Mato, X. R. (2001): Manual de gramática galega (Vigo: A Nosa Terra).

Freixeiro Mato, X. R. (2002) [1997]: Lingua galega: normalidade e conflito (Santiago de Compostela: Laiovento).

Freixeiro Mato, X. R. (2003): Gramática da lingua galega. Vol. IV: Gramática do texto (Vigo: A Nosa Terra).

Freixeiro Mato, X. R. (2003): “A lingua literaria decimonónica (II): aspectos gráfico-fónicos e morfosintácticos”, en Maleval, M. A. Tavares / Salinas Portugal, F. (orgs.), Estudos Galego-Brasileiros: 79-111 (Rio de Janeiro: Comunicação).

Freixeiro Mato, X. R. / Sánchez Rei, X. M. / Sanmartín Rei, G. (2005): A lingua literaria decimonónica (A Coruña: Universidade da Coruña).

García de Diego, V. (1984) [reimpr. facs. da ed. de 1909]: Elementos de gramática histórica gallega (Fonética-Morfología). Anexo 23 de Verba (Santiago de Compostela: Universidade de Santiago de Compostela).

García Negro, M. P. (2001): "Lamas Carvajal: a literatura galega utilitaria ao servizo da patria reivindicada", en Xornadas sobre V. Lamas Carvajal. Actas das xornadas realizadas pola Dirección Xeral de Promoción Cultural en Ourense (Santiago de Compostela: Xunta de Galicia / Consellería de Cultura, Comunicación Social e Turismo).

GRA = Mateus, M. H. Mira / Brito, A. M. / Duarte, I. / Faria, I. Hub / Frota, S. / Matos, G. / Oliveira, F. / Vigário, M. / Villalva, A. (2003) [1983], Gramática da Língua Portuguesa (Lisboa: Caminho).

Guiraud, P. (1964) [1961]: La gramática (Buenos Aires: Editorial Universitaria de Buenos Aires).

Henríquez Salido, M. C. (1986): “As gramáticas do galego do século XIX”, en Actas do I ${ }^{o}$ Congresso Internacional da Língua Galego-Portuguesa na Galiza: 443468 (Ourense: AGAL).

Hermida, C. (1992a): A reivindicación da lingua galega no rexurdimento (18401891). Escolma de textos (Santiago de Compostela: Consello da Cultura Galega).

Hermida, C. (1992b): Os precursores da normalización. Defensa e reivindicación da lingua galega no Rexurdimento (1840-1891) (Vigo: Xerais).

Hermida Gulías, C. (2004): Gramática práctica (Morfosintaxe) (Santiago de Compostela: Sotelo Blanco) 
Kossarik, M. (2002): "A tradição portuguesa no contexto da linguística europeia", en Head, B. F. / Teixeira, J. / Lemos, A. Sampaio / Barros, A. Leal de / Pereira, A. (orgs.), História da Língua e História da Gramática. Actas do Encontro: 181203 (Braga: Universidade do Minho).

Lewandowski, T. (1992): Diccionario de lingüística (Madrid: Cátedra).

López Varela, E. (2001): Unha casa para a lingua. A Real Academia Galega baixo a presidencia de Manuel Murguía (1905-1923) (A Coruña: Espiral Maior).

Lyons, J. (1986): Introducción en la lingüística teórica (Barcelona: Teide).

Martínez González, M. (1883): “Tratado sobre el modo de escribir y hablar con propiedad el dialecto gallego", en Martínez González, M., Poemas gallegos seguidos d'un tratado sobr'o modo de falar é escribir con propiedade ó dialeuto: 121-130 (Pontevedra: Tipografía de José M. Madrigal).

Mariño Paz, R. (2002): “A obra lingüística de Carvalho Calero”, en López, T. I Salinas, F. (eds.), Actas do Simposio Ricardo Carvalho Calero. Memoria do Século: 67-106 (A Coruña: Departamento de Galego-Portugués, Francés e Lingüística da Universidade da Coruña / Asociación Sócio-Pedagóxica Galega).

Mirás, F. (1864): Compendio de gramática gallega-castellana, con un vocabulario de nombres y versos gallegos y su correspondencia castellana, precedido de unos diálogos sobre diferentes temas. Un grandioso poema de 100 octavas titulado "La creación y la redención. Un extracto de Fábulas de los mejores fabulistas así como algunas del autor (Santiago de Compostela: Imprenta del Seminario Conciliar Central).

Moure, T. (2000): "Epistemoloxía lingüística", en Ramallo, F. / Rei-Doval, G. I Rodríguez Yáñez, X. P. (2000), Manual de Ciencias da Linguaxe: 35-62 (Vigo: Xerais).

Nagore, F. (1989) [1977]: Gramática de la Lengua Aragonesa (Zaragoza: Mira Editores).

Prieto Alonso, D. (1986): Prosodie et syntaxe. La position des clitiques en galicien-portugais (Groningue: Edición do autor).

R. A. [Ramón Alvariño, pseudónimo de Leandro Carré Alvarellos] (1919): Compendio de gramática galega (A Cruña: Imprenta Nova).

Rodríguez, M. R. (1900): “Apuntes gramaticales sobre el romance gallego de la Crónica Troyana”, en Martínez Salazar, A. (ed.), Crónica Troyana: 3-85 (A Coruña: Imprenta de la Casa de Misericordia).

Saco Arce, J. A. (1868): Gramática Gallega (Lugo: Imprenta de Soto Freire). 
Sánchez Rei, X. M. (2003): “A lingua literaria decimonónica (III): aspectos do léxico”, en Maleval, M. A. Tavares / Salinas Portugal, F. (orgs.), Estudos GalegoBrasileiros: 113-160 (Rio de Janeiro: Comunicação).

Sanmartín Rei, G. (2003): “A lingua literaria decimonónica (I): o contexto sociolingüístico" en Maleval, M. A. Tavares / Salinas Portugal, F. (orgs.), Estudos Galego-Brasileiros: 49-78 (Rio de Janeiro: Comunicação).

Sanmartín Rei, G. (2002): Os (pre)textos galegos (1863-1936) (Santiago de Compostela: Sotelo Blanco).

Santamarina, A. (1974): “Gramática”, en Gran Enciclopedia Gallega. Vol. XVI: 191195 (Santiago de Compostela / Xixón: Silverio Cañada Editor).

Santiago y Gómez, J. de (1918): Filología de la lengua gallega (Santiago de Compostela: Tipografía de El Eco Franciscano).

Valladares, M. (1970) [redixida en 1892]: Elementos de gramática gallega (Vigo: Galaxia).

Vázquez Corredoira, F. (1998): A Construção da Língua Portuguesa frente ao Castelhano. O Galego como Exemplo a contrario (Santiago de Compostela: Laiovento). 